\title{
Turfgrass Wear Stress: Effects of Golf Car and Tire Design
}

\author{
R.N. Carrow and B.J. Johnson \\ Department of Crop and Soil Science, Georgia Experiment Station, Griffin, \\ GA 30223-1797
}

Additional index words. traffic, golf car tire, bermudagrass, Cynodon sp.

\begin{abstract}
A turfgrass wear injury study was conducted at Griffin, Ga., on 'Tifway' bermudagrass (Cynodon dactylon $\mathrm{x}$ C. transvaalensis) using two golf car tires and three golf car types driven in a semicircular pattern to deliver 85 passes over the tread path plot area. Wear injury for the 14 days after wear was applied was assessed by visual quality, percent green coverage, leaf bruising, and verdure. Golf tire $\times$ car interactions occurred, but more wear occurred with the low pressure $\left(48 \times 10^{3} \mathrm{~Pa}\right)$, dimpled tread tire with flexible sidewalls than the commonly used bias ply (4-ply), V-shaped tread tire with more rigid sidewalls. Significant differences in wear damage occurred for golf car type but were influenced by tire design. Thus, selection of golf car tire and golf car type can influence the degree of wear injury on turfgrass sites.
\end{abstract}

Vehicle and foot traffic on recreational sites can cause physical damage to turfgrass shoot tissues (termed wear injury) as well as soil compaction. Depending on the nature of the traffic, wear can be manifested as injury from pressure, abrasion, scuffing, or tearing (Beard, 1973). Wear stress is a predominant stress on high-traffic sites, requiring considerable management skill and cost to reduce injury.

Carrow and Petrovic (1992) reviewed research on mechanisms of turfgrass wear tolerance; plant, soil, and traffic factors enhancing wear; and cultural practices to minimize injury. Two factors affecting wear damage are tire design and traffic patterns. Burton and Lance (1966) reported more wear damage from narrow, high-pressure tires; sharp turns; and repeated passes over an area. Since that time, wide, pneumatic tires without deep lugs have been used extensively for turfgrass maintenance and golf car vehicles.

Carrow and Johnson (1989) assessed wear damage on 'Tifway' bermudagrass from biasply vs. radial tires and treads of sawtooth, chevron, and ribbed configurations with all tires at $124 \times 10^{3} \mathrm{~Pa}$ pressure. Also included were golf car types (two) and traffic patterns. Of the seven tires evaluated, only minor differences in turfgrass wear injury occurred within 4 days of wear applications and only minor differences in wear were noted between the two golf cars. The most important factors influencing the extent of wear damage were moderately sharp turns (vs. straight-line traffic) and the number of repeated passes over a turf.

Received for publication 19 Oct. 1995. Accepted for publication 26 May 1996. We thank the Goodyear Tire and Rubber Co., Akron, Ohio, for their financial support of this project. The cost of publishing this paper was defrayed in part by the payment of page charges. Under postal regulations, this paper therefore must be hereby marked advertisement solely to indicate this fact.
Changes continue in golf car tire technology that may influence turfgrass wear, such as lower-pressure tires, tread configuration, more flexible sidewalls, and tire rim composition (Nesbitt, 1992). Also, increasing use of golf cars may enhance wear (Gast, 1991). The purposes of this project were to 1) determine the influence of two tire designs on turfgrass wear injury and 2) evaluate whether golf car type influenced turfgrass wear injury.

\section{Materials and Methods}

The project was conducted on Tifway bermudagrass at the Georgia Experiment Station at Griffin in Summer 1992. The turfgrass was mowed to $1.6 \mathrm{~cm}$ high three times per week with clippings returned. Irrigation was applied to prevent visible drought stress. The project was run twice. The first run (25 June to 9 July 1992) was on an Appling sandy clay loam (clayey, kaolinitic, thermic Typic Kanhapludult) with $1.7 \%$ organic matter (loss by ignition), $55.1 \%$ sand, $21.6 \%$ silt, and $23.3 \%$ clay, while the second (12 to 26 Aug.) run was on an Appling loamy sand with $2.2 \%$ organic

Table 1. Weather conditions during the study to find the influence of golf car tire design and golf car model on wear of bermudagrass turf.

\begin{tabular}{|c|c|c|c|c|c|}
\hline \multirow{3}{*}{$\begin{array}{l}\text { Dates of studies } \\
\text { and periods of } \\
\text { evaluation (DAT)y }\end{array}$} & \multicolumn{4}{|c|}{ Avg weather conditions ${ }^{2}$} & \multirow{3}{*}{$\begin{array}{c}\text { Total } \\
\text { rainfall }(\mathrm{mm})\end{array}$} \\
\hline & \multicolumn{2}{|c|}{ Air temp $\left({ }^{\circ} \mathrm{C}\right)$} & \multirow{2}{*}{$\frac{\text { Humidity }(\%)}{\text { Min }}$} & \multirow{2}{*}{$\begin{array}{c}\text { Total solar } \\
\text { radiation }\left(\mathrm{MJ} \cdot \mathrm{m}^{-2}\right)\end{array}$} & \\
\hline & $\overline{M a x}$ & Min & & & \\
\hline \multicolumn{6}{|c|}{25 June-9 July 1992} \\
\hline 0 to $4 \mathrm{DAT}$ & 30.8 & 19.2 & 54 & 22.5 & $12^{\mathrm{x}}$ \\
\hline 5 to 7 DAT & 30.2 & 20.4 & 66 & 18.4 & 37 \\
\hline 8 to 14 DAT & 32.3 & 20.5 & 47 & 24.6 & $\begin{array}{r}5 \\
54\end{array}$ \\
\hline \multicolumn{6}{|c|}{ 12-26 Аия. 1992} \\
\hline 0 to $4 \mathrm{DAT}$ & 26.8 & 19.0 & 72 & 13.8 & $57^{\mathrm{w}}$ \\
\hline 5 to $7 \mathrm{DAT}$ & 27.9 & 18.1 & 63 & 16.5 & 3 \\
\hline 8 to 14 DAT & 28.0 & 20.1 & 71 & 13.6 & $\frac{91}{151}$ \\
\hline
\end{tabular}

${ }^{{ }^{2} \text { Weather data provided by Gerrit Hoogenboom, Dept. of Biological and Agricultural Engineering, Univ. of }}$ Georgia, Griffin.

${ }^{\mathrm{D} D A T}=$ days after wear treatment.

'Rainfall on 2 DAT was $11 \mathrm{~mm}$ and on 7 DAT was $20 \mathrm{~mm}$.

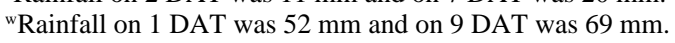


Table 2. Golf car tires and cars used in the study to determine the influence of golf car tire design and golf car model on wear of bermudagrass turf.

\begin{tabular}{|c|c|c|c|}
\hline Variable & Description & Tread & $\begin{array}{c}\text { Air } \\
\text { pressure }(\mathrm{Pa}) \\
\end{array}$ \\
\hline \multicolumn{4}{|l|}{ Tires $^{2}$} \\
\hline PR & $\begin{array}{l}\text { Power Rib (0F0220), } \\
18 \times 8.50-8 \mathrm{NHS}, 4 \text { ply, tubeless, } \\
\text { steel rim }\end{array}$ & $\begin{array}{l}4.8 \text { mm deep, } \\
\text { chevron or } \\
\text { V-shaped }\end{array}$ & $124 \times 10^{3}$ \\
\hline B & $\begin{array}{l}\text { Bogie Buster }(0 \mathrm{~F} 0510 \mathrm{C}) \\
18 \times 8.50-\mathrm{R} 8 \mathrm{NHS}, 2 \text { ply, radial, } \\
\text { composite rim }\end{array}$ & $\begin{array}{l}1.0 \text { mm deep, } \\
\text { dimpled }\end{array}$ & $48 \times 10^{3}$ \\
\hline \multicolumn{4}{|c|}{ - $\mathrm{T}$ - } \\
\hline Club & $\begin{array}{l}\text { Club Car (A8929), 4-wheel } \\
\text { electric, } 381 \mathrm{~kg} \text { with batteries }\end{array}$ & --- & --- \\
\hline EZ-GO & $\begin{array}{l}\text { EZ-GO (487678), 4-wheel } \\
\text { electric, } 433 \mathrm{~kg} \text { with batteries }\end{array}$ & -- & --- \\
\hline Yamaha & $\begin{array}{c}\text { Yamaha (JG6-000333), 4-wheel } \\
\text { electric, } 453 \mathrm{~kg} \text { with batteries }\end{array}$ & --- & --- \\
\hline
\end{tabular}

${ }^{2}$ Goodyear Tire and Rubber Co., Akron, Ohio.

${ }^{y}$ Club Car, Augusta, Ga.; EZ-GO Textron, Augusta, Ga.; Yamaha Motor Corp. USA, Cypress, Calif. ${ }^{x}$ Golf car weights are without driver. Batteries added $177 \mathrm{~kg}$; driver weighed $80 \mathrm{~kg}$.
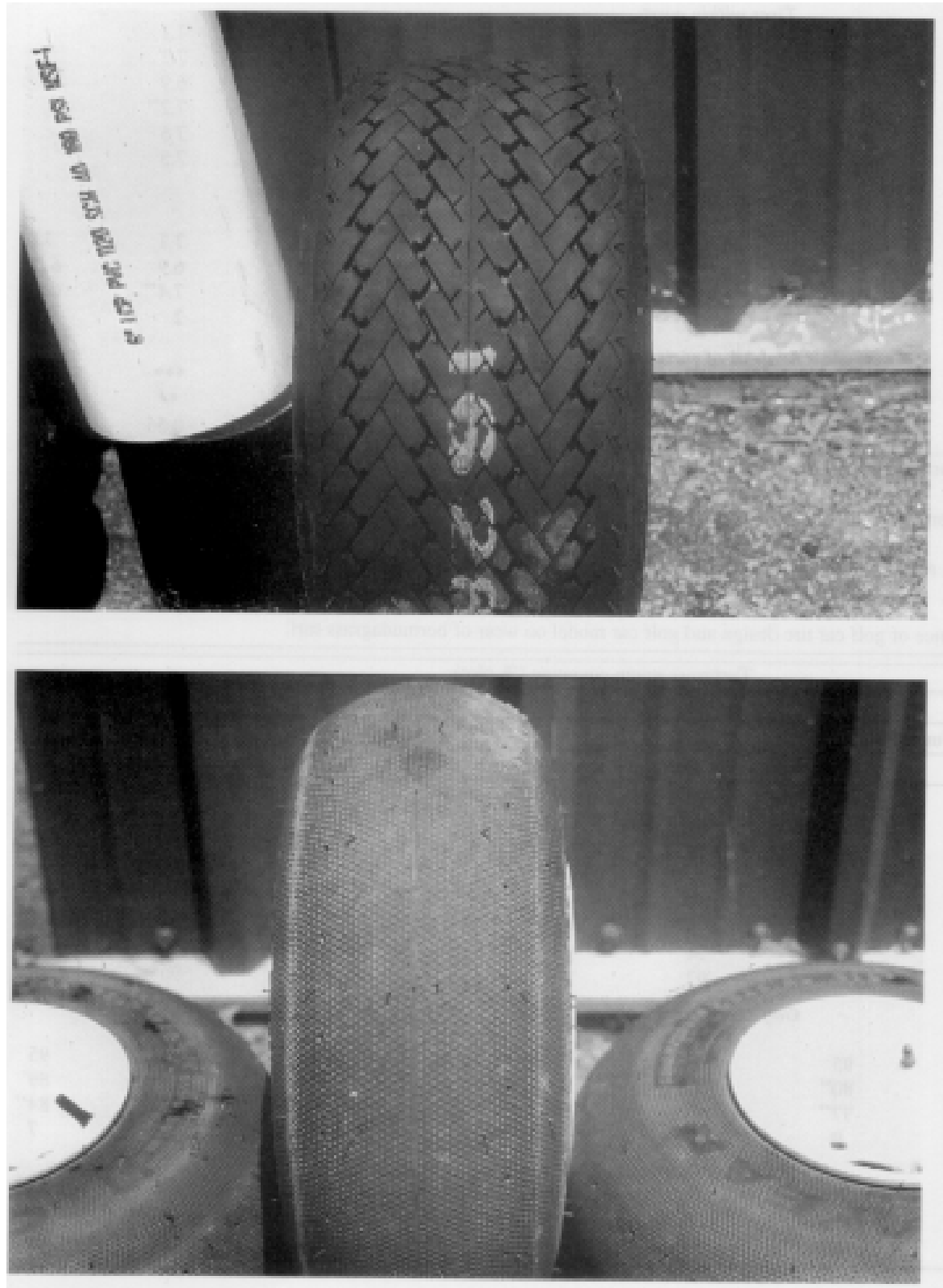

Fig. 1. Golf car tires used to determine the influence of golf car tire design and golf car model on wear of bermudagrass turf. (top) Power Rib and (bottom) Bogie Buster. (visual rating, percent cover estimated within $\pm 5 \%$ ) also was estimated to indicate loss of turfgrass stand. If loss of cover is due to leaves stripped from the stem or shredded on the stem so that they die, then coverage decreases rapidly after wear, but recovers quickly as new leaves develop. However, if loss of coverage is due to destruction of the stem area and stolons, then injury appears rapidly, but recovery is very slow.

Leaf bruising ratings were an integration of stripping of leaves from the stem, leaves shredded but still attached to stems, bruising/ discoloration of leaves, and wilt/browning of leaves, all of which were observed. Ratings were on a percentage (estimated $\pm 5 \%$ ) of leaves exhibiting any of these symptoms.

Verdure is defined as the amount of live green tissue from the upper thatch surface to the routine mowing height line. It is a measure of aboveground plant "yield." Verdure was obtained from two 5.7-cm-diameter cores per plot on each sample date with live tissue separated, dried at $70^{\circ} \mathrm{C}$ for $24 \mathrm{~h}$, and weighed.

Due to time (runs) interactions, data are presented for both runs. Orthogonal paired comparisons were selected to compare tires within a golf car since the tire $\times$ golf car interaction was significant on most dates for most of the variables measured (SAS Inst., 1988). Comparison of golf cars was made only for the Power Rib tire because 1) the maximum orthogonal paired comparisons that can be made is $t-1$, where $t=$ number of treatments. Tire comparisons within a golf car required three comparisons, leaving only two that were assigned to the golf cars within the Power Rib tire, and 2) the Bogie Buster tire was experimental and very different from commonly used tires, such as the Power Rib. Thus, the Power Rib appeared to be a better choice for comparing golf cars.

\section{Results}

Visual quality. Tire design influenced turfgrass visual quality in both studies, but a car $\times$ tire interaction occurred on five out of eight rating dates (Table 3). The B tire on the EZGO car resulted in lower visual quality than the PR tire on seven of eight dates; on the Club Car, the B tire caused lower quality than the PR design for 1 to 4 DAT, but then the trend reversed from 7 to 14 DAT. Thus, the B tire exhibited lower quality ratings than the PR tire on three of eight dates, and higher quality on four dates. When mounted on the Yamaha car, the B design caused lower quality than the PR tire on three of eight dates (but the magnitude was not large) and higher quality on one date.

As an overall evaluation for the semicircular driving pattern, an average of the visual quality ratings across all DAT, all golf cars, and both trial periods should reflect what would be visible in the field over the first 2 weeks after injury. Based on this criterion (i.e., using turf visual quality ratings and a rating scale of $9=$ ideal $)$, main tire rankings were control $(7.8$ a), PR (6.5 b), and B (6.1 c) with statistical differences by Duncan's multiple range test (MRT; at $P \leq 0.05$ ). 
To determine the influence of golf car model on bermudagrass wear as exhibited by visual quality, the PR tire was used (Table 3). Compared to the EZ-GO car, the Club Car resulted in lower visual quality on four out of eight dates, while the Yamaha caused lower quality on six dates, but higher quality on one date. Club Car and Yamaha treated plots had lower visual quality than the EZ-GO plots when quality was averaged over all dates.

Green coverage. A car $\times$ tire interaction was evident for turfgrass green coverage percentage on five out of eight rating dates (Table
4). Relative to the PR design, B tire resulted in less green coverage on seven rating dates when mounted on the EZ-GO car, and lower green coverage on three out of eight dates on the Yamaha car. With the Club Car, the B tire resulted in less green coverage than the PR tire on three dates and higher on one date out of eight. A comparison of green coverage across all DAT, golf cars, and trial periods revealed a ranking of control (99\% a), PR (89\% b), and B $(83 \% \mathrm{c})$ based on Duncan's MRT $(P \leq 0.05)$.

Green coverage was influenced by golf car model when the PR tire was used (Table 4).
Relative to the EZ-GO car, lower green turf coverage was evident on four dates for Club Car and three dates for Yamaha. When averaged over all rating dates, the EZ-GO car treated plots had higher green coverage than those with the Club Car or Yamaha.

Leaf bruising and verdure. The B tire design resulted in more leaf bruising than the PR tire on all rating dates for the Club Car and Yamaha, and on three out of four dates for the EZ-GO car (Table 5). When data were averaged across all DAT, golf cars, and study periods, leaf bruising comparisons were con-

Table 3. Turfgrass visual quality data for the influence of golf car tire design and golf car model on wear of bermudagrass turf.

\begin{tabular}{|c|c|c|c|c|c|c|c|c|c|}
\hline \multirow[b]{4}{*}{ Treatments/contrasts } & \multicolumn{9}{|c|}{ Turfgrass visual quality $^{z}$} \\
\hline & \multicolumn{9}{|c|}{ Test period } \\
\hline & \multicolumn{4}{|c|}{ 25 June-9 July 1992} & \multicolumn{5}{|c|}{ 12-26 Aug. 1992} \\
\hline & $1 \mathrm{DAT}^{\mathrm{y}}$ & 4 DAT & $7 \mathrm{DAT}$ & $14 \mathrm{DAT}$ & $1 \mathrm{DAT}$ & 4 DAT & $7 \mathrm{DAT}$ & 14 DAT & $\operatorname{Avg}^{x}$ \\
\hline Control & 7.9 & 7.9 & 8.0 & 7.6 & 8.1 & 7.9 & 7.7 & 7.4 & \\
\hline \multicolumn{10}{|c|}{ Tires within cars ${ }^{w}$} \\
\hline PR vs. & 7.4 & 6.7 & 7.0 & 7.5 & 6.9 & 6.7 & 6.9 & 7.1 & \\
\hline B on EZ-GO & $5.4^{* * *}$ & $5.2^{* * *}$ & $5.9^{* * *}$ & $6.6^{* * *}$ & $6.1^{* *}$ & $5.9^{* * * *}$ & $6.5^{* *}$ & 7.2 & \\
\hline PR vs. & 5.9 & 5.2 & 5.4 & 6.2 & 6.9 & 6.7 & 6.8 & 6.9 & \\
\hline B on Club & $4.8^{* * *}$ & $4.7^{* *}$ & $6.2^{* *}$ & $6.8^{* *}$ & 6.6 & $6.4^{* * *}$ & $7.1^{*}$ & $7.2^{* *}$ & \\
\hline PR vs. & 4.7 & 4.3 & 5.1 & 7.1 & 6.6 & 6.4 & 7.0 & 7.5 & \\
\hline B on Yamaha & $6.1^{* * * *}$ & $3.7^{* *}$ & 5.0 & 6.8 & $6.0^{* *}$ & $5.8^{* * * *}$ & 6.8 & 7.5 & \\
\hline \multicolumn{10}{|c|}{ Golf cars across tires } \\
\hline Power Rib & & & & & & & & & \\
\hline EZ-GO vs. & 7.4 & 6.7 & 7.0 & 7.5 & 6.9 & 6.7 & 6.9 & 7.1 & 7.0 \\
\hline Club & $5.9^{* * * *}$ & $5.2^{* * * *}$ & $5.4^{* * * *}$ & $6.2^{* * * *}$ & 6.9 & 6.7 & 6.8 & 6.9 & $6.3^{* *}$ \\
\hline Yamaha & $4.7^{* * *}$ & $4.3^{* * *}$ & $5.1^{* * * *}$ & $7.1^{* *}$ & $6.6^{* *}$ & $6.4^{* *}$ & 7.0 & $7.4^{* *}$ & $6.1^{* *}$ \\
\hline $\mathrm{CV}(\%)$ & 7 & 8 & 8 & 5 & 6 & 4 & 4 & 2 & 7 \\
\hline \multicolumn{10}{|c|}{ Analysis of variance } \\
\hline Car & $* * *$ & $* * *$ & $* * *$ & $* * *$ & 0.14 & $* * *$ & * & $* * *$ & $* * *$ \\
\hline Tire & $* * *$ & $* * *$ & 0.55 & 0.12 & *** & $* * *$ & 0.39 & ** & $* *$ \\
\hline Car $\times$ tire & $* * *$ & ** & $* * *$ & $* * *$ & 0.55 & 0.15 & $* *$ & 0.55 & ** \\
\hline
\end{tabular}

${ }^{2}$ Visual quality: 9.0 = ideal shoot density, color, uniformity; $1.0=$ no live turf.

${ }^{\mathrm{y}} \mathrm{DAT}=$ days after wear treatment application.

${ }^{\mathrm{x}}$ Average $=$ averaged across all DAT and both trial periods.

${ }^{w} \mathrm{PR}=$ Power Rib; $\mathrm{B}=$ Bogie Buster.

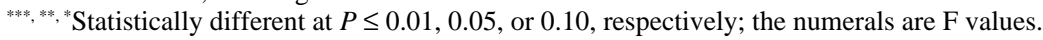

Table 4. Turfgrass green coverage data for the influence of golf car tire design and golf car model on wear of bermudagrass turf.

\begin{tabular}{|c|c|c|c|c|c|c|c|c|c|}
\hline \multirow[b]{4}{*}{ Treatments/contrasts } & \multicolumn{9}{|c|}{ Turfgrass green coverage (\% plot) } \\
\hline & \multicolumn{9}{|c|}{ Test period } \\
\hline & \multicolumn{4}{|c|}{25 June-9 July 1992} & \multicolumn{4}{|c|}{ 12-26 Aug. 1992} & \multirow[b]{2}{*}{$\operatorname{Avg}^{y}$} \\
\hline & $\overline{1 \mathrm{DAT}^{\mathrm{z}}}$ & 4 DAT & $7 \mathrm{DAT}$ & $14 \mathrm{DAT}$ & $1 \mathrm{DAT}$ & 4 DAT & $7 \mathrm{DAT}$ & $14 \mathrm{DAT}$ & \\
\hline Control & 100 & 100 & 100 & 100 & 99 & 98 & 98 & 97 & \\
\hline \multicolumn{10}{|c|}{ Tires within cars $^{x}$} \\
\hline PR vs. & 100 & 95 & 95 & 98 & 96 & 93 & 93 & 92 & \\
\hline B on EZ-GO & $64^{* * *}$ & $68^{* * *}$ & $80^{* * *}$ & $91^{* * *}$ & $92^{* *}$ & $87^{* * * *}$ & $90^{*}$ & 93 & \\
\hline PR vs. & 85 & 77 & 80 & 89 & 96 & 95 & 94 & 93 & \\
\hline B on Club & $61^{* * *}$ & $58^{* * *}$ & 85 & $95^{* * * *}$ & 95 & $92^{* * * *}$ & 93 & 95 & \\
\hline PR vs. & 88 & 40 & 77 & 94 & 93 & 92 & 94 & 96 & \\
\hline B on Yamaha & $60^{* * *}$ & 48 & 75 & 97 & $89^{* *}$ & $89^{* * *}$ & 93 & 96 & \\
\hline \multicolumn{10}{|c|}{ Golf cars across tires } \\
\hline Power Rib & & & & & & & & & \\
\hline EZ-GO vs. & 100 & 95 & 95 & 98 & 96 & 93 & 93 & 92 & 95 \\
\hline Club & $85^{* * * *}$ & $77^{* * * *}$ & $80^{* *}$ & $89^{*}$ & 96 & 95 & 94 & 93 & $89^{*}$ \\
\hline Yamaha & $88^{* *}$ & $40^{* * *}$ & $77^{* *}$ & 94 & 93 & 92 & 94 & 96 & $84^{* *}$ \\
\hline $\mathrm{CV}(\%)$ & 11 & 11 & 9 & 3 & 3 & 2 & 3 & 2 & 7 \\
\hline \multicolumn{10}{|c|}{ Analysis of variance } \\
\hline Car & $*$ & $* * *$ & $* *$ & $* *$ & $* * *$ & $* * *$ & 0.28 & $* * *$ & $* * *$ \\
\hline Tire & $* * *$ & $* * *$ & 0.40 & 0.26 & $* * *$ & $* * *$ & $*$ & 0.24 & $* *$ \\
\hline Car $\times$ tire & $* * *$ & $* *$ & $* *$ & $* * *$ & 0.44 & $*$ & 0.72 & 0.64 & $* *$ \\
\hline
\end{tabular}

${ }^{2} \mathrm{DAT}=$ days after wear treatment application.

${ }^{\mathrm{y}}$ Average $=$ averaged across all DAT and both trial periods.

${ }^{x} \mathrm{PR}=$ Power Rib; $\mathrm{B}=$ Bogie Buster.

${ }^{* * * * * * *, *}$ Statistically different at $P \leq 0.01,0.05$, or 0.10 , respectively; the numerals are $\mathrm{F}$ values. 
Table 5. Data on leaf bruising and verdure for the influence of golf car tire design and golf care model on wear of bermudagrass turf.

\begin{tabular}{|c|c|c|c|c|c|c|c|c|c|c|}
\hline \multirow[b]{4}{*}{ Treatments/contrasts } & \multicolumn{5}{|c|}{ Leaf bruising (\% leaves) } & \multicolumn{5}{|c|}{ Verdure (\% control) } \\
\hline & \multicolumn{5}{|c|}{ Test period } & \multicolumn{5}{|c|}{ Test period } \\
\hline & \multicolumn{2}{|c|}{25 June-July 1992} & \multicolumn{3}{|c|}{ 12-26 Aug. 1992} & \multicolumn{2}{|c|}{ 25-26 June 1992} & \multicolumn{3}{|c|}{ 12-26 Aug. 1992} \\
\hline & $1 \mathrm{DAT}^{2}$ & $4 \mathrm{DAT}$ & $1 \mathrm{DAT}$ & $4 \mathrm{DAT}$ & $\mathrm{Avg}^{y}$ & $7 \mathrm{DAT}$ & $14 \mathrm{DAT}$ & $7 \mathrm{DAT}$ & 14 DAT & $\operatorname{Avg}^{y}$ \\
\hline Control & 0 & 0 & 0 & 0 & & 100 & 100 & 100 & 100 & \\
\hline \multicolumn{11}{|c|}{ Tires within cars $^{x}$} \\
\hline PR vs. & 35 & 65 & 9 & 30 & & 59 & 91 & 65 & 76 & \\
\hline B on EZ-GO & $66^{* * * *}$ & 60 & $26^{* * *}$ & $53^{* * *}$ & & 38 & 85 & 55 & 102 & \\
\hline PR vs & 46 & 60 & 8 & 29 & & 62 & 108 & 54 & 80 & \\
\hline B on Club & $93^{* * *}$ & $80^{* * *}$ & $16^{* *}$ & $50^{* * * *}$ & & 77 & 87 & $81^{*}$ & 97 & \\
\hline PR vs. & 88 & 84 & 19 & 23 & & 20 & 112 & 78 & 105 & \\
\hline B on Yamaha & $98^{* *}$ & $96^{*}$ & $28^{* * *}$ & $53^{* * *}$ & & $57^{*}$ & 93 & 62 & 123 & \\
\hline \multicolumn{11}{|c|}{ Golf cars across tires } \\
\hline \multicolumn{11}{|l|}{ Power Rib } \\
\hline EZ-GO vs. & 35 & 65 & 9 & 30 & 35 & 59 & 91 & 65 & 76 & 73 \\
\hline Club & 46 & 60 & 8 & 29 & 36 & 62 & 108 & 54 & 80 & 76 \\
\hline Yamaha & $88^{* * *}$ & $84^{*}$ & $19^{*}$ & 23 & $54^{* *}$ & $20^{* * *}$ & $112^{*}$ & $78^{*}$ & $105^{* *}$ & 79 \\
\hline $\mathrm{CV}(\%)$ & 10 & 14 & 28 & 19 & 18 & 53 & 22 & 32 & 29 & 28 \\
\hline \multicolumn{11}{|c|}{ Analysis of variance } \\
\hline Car & $* * *$ & $* * *$ & $* * *$ & 0.58 & $* * *$ & $*$ & 0.37 & 0.60 & 0.15 & 0.42 \\
\hline Tire & $* * *$ & ** & $* * *$ & $* * *$ & $* * *$ & 0.36 & $*$ & 0.97 & $*$ & 0.30 \\
\hline Car $\times$ tire & $* * *$ & $*$ & 0.12 & 0.42 & $* *$ & 0.14 & 0.73 & 0.14 & 0.93 & 0.64 \\
\hline
\end{tabular}

${ }^{2}$ DAT $=$ days after wear treatment application.

${ }^{\mathrm{y}}$ Average $=$ averaged across all DAT and both trial periods.

${ }^{x} \mathrm{PR}=$ Power Rib; B = Bogie Buster.

${ }^{* * * * * *, *}$ Statistically different at $P \leq 0.01,0.05$, and 0.10 , respectively; the numerals are $\mathrm{F}$ values.

trol (0\% a), PR ( $41 \%$ b), and B $(60 \%$ c) based on Duncan's MRT $(P \leq 0.05)$.

Golf car model influenced the degree of leaf bruising, with the Yamaha causing more leaf bruising on three out of four rating dates with the PR tire (Table 5). Averaging the data across DAT and study periods demonstrated more leaf bruising for the Yamaha than the EZ-GO.

Significant differences in verdure were infrequent (Table 5). A contributing factor was the high coefficient of variability for verdure data. The B tire resulted in higher verdure than the PR tire on one date for the Club Car and Yamaha. Comparison of golf car models with the PR tire demonstrated less verdure for the Yamaha compared to the EZ-GO car on one date but greater verdure on three dates (Table 5).

\section{Discussion}

The PR tire design caused least turfgrass wear injury, whether based on visual quality, turfgrass green coverage, or leaf bruising (Tables 3-5). Nesbitt (1992) noted that radial tires have lower rolling resistance than biasply tires, but more flexible sidewalls and lower inflation pressures. When turning, the B tire appeared to be more flexible than the PR. Perhaps the much lower pressure plus flexible sidewalls contributed to greater wear on turns. Also, the dimpled tread configuration of the B tire versus the chevron (V-shaped) tread of the PR may have caused greater wear (Fig. 1). The PR was reported to cause less wear injury than a smooth, straight ribbed tire and a modified rib with a limited chevron tread (Carrow and Johnson, 1989) in a semicircular driving pattern at pressure of $124 \times 10^{3} \mathrm{~Pa}$ for all tires.
Additionally, rubber composition may influence tire wear on paved surfaces and, potentially, wear induced by the tire on turfgrass stands (Nesbitt, 1992).

With the PR tire, the EZ-GO car caused less wear than Club Car or Yamaha based on visual quality and turfgrass green coverage (Tables 3 and 4). Also, leaf bruising was less for EZ-GO than Yamaha (Table 5). In a similar study, turf wear damage was the same for a EZ-GO vs. Club Car across three bias-ply tires maintained at equal pressure (Carrow and Johnson, 1989). However, the data in the current study suggests that golf car type can influence turfgrass wear and should be investigated in more detail.

Climatic conditions influenced golf cartire results. In the June trial, when the weather was hot and dry for the first 2 days of the study, the EZ-GO car caused less loss of visual quality, percent green turf coverage, and leaf bruising than the Club or Yamaha cars (Tables 3 and 4). However, in August, with cooler, humid conditions, differences between EZ-GO and the other cars were less dramatic and consistent. Since differing cars from each manufacturer were used in the two trials (but same model), this difference could contribute to the lack of consistency between trial runs just as weather could. Since hot, dry weather appears to enhance wear injury, turf managers should take greater care in traffic control during such periods.

Comparison of turfgrass wear injury data provided insight into leaf bruising as affected by golf car tire and golf car model. For the Club Car, green cover was reduced for the B tire at 1 to 4 DAT and leaf bruising/shredding enhanced (Tables 4 and 5), but the turfgrass initially injured by the B tire tended to exhibit somewhat higher verdure (Table 5) and green cover (Table 4) between 7 to 14 DAT than that exposed to the PR. Apparently, the initial leaf bruising/shredding by the B tire was unsightly, but not severe and these leaves recovered rapidly and/or new leaves quickly initiated. The somewhat greater wear damage by the PR from 7 to 14DAT may be due to the initial leaf bruising/shredding. While this damage was less apparent than that for the $\mathrm{B}$, it was more serious, i.e., leaves were stripped from stems or stems were damaged. Since leaf bruising ratings were an integrated value of leaves shredded on the stem, leaves shredding/ removed from the stem, and severe bruising/ discoloration of leaves, these data would strongly suggest that in future studies, the initial "leaf bruising" should be rated by its components instead of as an integrated value.

\section{Literature Cited}

Beard, J.B. 1973. Turfgrass: Science and culture. Prentice-Hall, Englewood Cliffs, N.J.

Burton, G.W. and C. Lance. 1966. Golf car versus grass. Golf Superintendent 34(1):66-70.

Carrow, R.N. and B.J. Johnson. 1989. Turfgrass wear as affected by golf car tire design and traffic patterns. J. Amer. Soc. Hort. Sci. 114:240-246.

Carrow, R.N. and A.M. Petrovic. 1992. Effects of traffic on turfgrasses. In: D.W. Waddington, R.N. Carrow, and R.C. Shearman (eds.). Turfgrass Monogr. 32. Amer. Soc. Agron., Madison, Wis.

Gast, C. 1991. Learning to live with golf cart traffic. USGA Green Section Record 29(5):9-11.

Nesbitt, S. 1992. Trends in treads. Golf Course Mgt. 60(10):73-74.

SAS Institute. 1988. SAS user's guide, release 6.03. SAS Inst., Cary, N.C. 